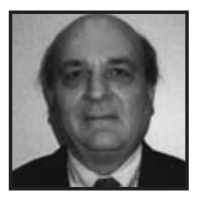

\title{
Leadership and Conceptions of Organization: Contours of the Distributed Perspective
}

\author{
Manuel Crespo, Université de Montréal
}

\begin{abstract}
This paper discusses the theoretical bases of various leadership perspectives and focuses in on one of them: distributed leadership. The learning organization conception of the sociology of organizations is proposed as the theoretical support of distributed leadership. Although a growing number of research findings point to the effectiveness of this perspective on school outcomes, there is need for further research in this area. To be successfully enacted, distributed leadership should be exerted in an organization which truly espouses the principles of a learning organization.
\end{abstract}

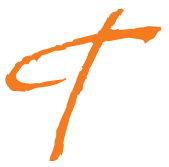

he theme of leadership in the realm of education is at the forefront of research and professional development efforts. The question in the minds of researchers and practitioners is invariably whether one or another educational leadership perspective is effective. This article focuses on distributed leadership. The concept can be defined provisionally as the collective participation in organizational leadership and management. It is some fifty years old, and builds on the discussion by Gibb (1954) and Bowess and Seashore (1966) about the possibility of a kind of leadership that transcends individual authority and responsibility. This idea did not retain the attention of researchers and practitioners in the following decades, however. It was only in the 1990s that the concept surfaced and became the focus of serious consideration in the research literature (Timperley, 2005). To gain a better understanding of the organizational roots of this leadership perspective and its effectiveness, it is useful to ground the analysis in a comparative framework that characterizes other leadership perspectives and discusses their 
organizational underpinnings. ${ }^{1}$ In a context of decentralization and local self-management in the education sector in a large number of countries, both developed and developing, the conception of power sharing favoured by a distribution of leadership merits full attention from all those who seek alternative ways of enhancing organizational effectiveness in a rapidly changing world. The paper has three sections: the first section presents an overview of four major conceptions of organizational behaviour; the second section links different models of leadership to these conceptions of organizational behaviour; and the third section comments on the effectiveness of distributed leadership. As way of conclusion, some constraints about adopting a distributed leadership approach in educational organizations will be discussed.

\section{Some Major Conceptions of Organizational Behaviour}

Authors within the tradition of the sociology of organizations have developed several conceptions of organizational behaviour. Four major conceptions of organizational behaviour will be outlined: the classical conception, the human relations conception, the contingency conception and the learning organization conception. These conceptions of organizational behaviour are at the root of particular leadership perspectives. The underlying assumption is that a correlation exists between the portrayed characteristics of the structure and functioning of an organization and the type of leadership exerted. It has been argued that the characterization of a particular organization presupposes a specific type of leadership. It is not the intention of this paper to discuss all four major conceptions of organizational behaviour in a thorough way. My objective is more modest. I attempt to provide a theoretical background that might serve as a framework for understanding the conceptual basis of distributed leadership.

\section{The classical conception of organizational behaviour}

This conception views the organization as a top-down structure with a clear delineation of authority, strict division of work, standardization of tasks, vertical flow of information, concentration of expertise on the top, tight supervision within a preestablished span of control and incentive schemes for performance. There are several interpretations of this conception. Among them, two are prominent: "scientific management" (Taylor, 1911) and "bureaucracy" (Weber, 1968). 
Taylor (1911) proposed a "science of work" embedded in four general principles: 1) the development of strict procedures for the execution of each element of a worker's task; 2) the methodical selection, preparation and development of workers; 3 ) the sustained cooperation between managers and workers to ensure that work is done according to specified procedures; and 4) a division of work between managers and workers, the former being responsible for the determination of work procedures and the latter responsible for the execution.

For Weber (1968), the bureaucratic model of organization is the best arrangement to cope with the demands of the industrial society. Bureaucracy is based on legal/rational authority, one of the three legitimate authorities according to Weber (1968), the other two being the traditional and the charismatic. The ideal type of bureaucracy consists of the following aspects: 1) members are free and they accomplish the objective duties of their function; 2 ) hierarchy of functions; 3 ) competencies required by each function; 4) open selection; 5) professional competencies of incumbents; 6) contracted work conditions; 7) exclusive work dedication; 8) career ladder; 9) non-ownership of the employee's position; and 10) strict and homogeneous discipline and control.

Mintzberg (1979) considers the bureaucratic structural model among the structural configurations he analyzes. His "mechanical bureaucracy" has several characteristics of the Taylorian model: strategic apex, hierarchical line, and operational center. But he adds two structural elements that were absent in Taylor (1911): technostructure and logistical support. The technostructure requires functions such as planning, research and advising to achieve bureaucratic effectiveness. The logistical support includes all those units that support the day-to-day functioning of the bureaucratic organization (personnel, maintenance, transportation, communication, public relations).

\section{The human relations conception of organizational behaviour}

When Mayo (1968) and his colleagues initiated their experiments at the Hawthorne plant of Western Electric in the late 1920s and early 1930s, they did not know that an intriguing finding would lead to the development of one of the most influential schools of management. Following the lines of research based in scientific management, then the dominant theory of management, they attempted to analyze the impact of different work conditions (light, breaks during work) on productivity. 
The results, however, could not be interpreted from the classical/mechanical perspective as there was an increase in productivity, even when the work conditions were not at their best (declining light). Moreover, after a number of variations in the timings of breaks during work, the participants in the experiments had higher outputs than at the beginning despite the fact that the conditions were the same. Thus, other factors different from work conditions, as proposed by scientific management, were intervening to increase organizational productivity. These other factors were deemed to be "human," and defined as the development of group cohesiveness, the increase in self-esteem, and the feeling of personal accomplishment. All these human aspects resulted from the perceived importance of having been chosen to participate in a prestigious research experiment. (Mayo, 1968)

This pivotal finding of the relationship between productivity and human factors served as basis for an impressive research effort. In that vein, and as an indication of the relevance of this line of research, it is worth mentioning, among others, the works by Likert (1961) on participative management, McGregor's study (1960) on the relevance of a " $\mathrm{Y}$ " theory that emphasized the importance of the human factor (as opposed to an " $X$ " theory that does not take into account this factor); and Argyris' (1964) "mixed model" of organizational effectiveness where an integration of both structural and human factors are conducive to enhanced productivity and work satisfaction.

\section{The structural contingency conception of organizational behaviour}

The same uneasiness to explain research results from the leading theoretical perspective of the time, in this case, the scientific management and human relations approach, led Woodward (1965) to propose an alternative interpretation of structural and functional arrangements. In her study of 100 industries of south England, Woodward found that several organizational arrangements, such as span of control, flow and support of communications, and work organization, could not be explained either from the classical/mechanical or human relations perspective. She found that these differences were linked to the use of different production technologies. This insight was pushed further ahead by Emery and Trist (1965) who attributed a "causal texture" to different types of organizational environments in the determination of organizational arrangements.

It is, however, Lawrence and Lorsh (1967) and Lorsh and Morse (1974) who formalized the relationships between environmental constraints, organizational arrangements, members' characteristics, and organizational effectiveness. They con- 
cluded that there was no "one way" for effective management and that the type of effective management depends on the characteristics and constraints of organizational environments. If the environment of the organization is not complex, organizational arrangements can be "mechanical." However, if the environment of the organization is complex, then organizational arrangements should be of the organic type: less hierarchy; more lateral communications; knowledge dispersed throughout the organization and not only at the top; and teamwork. When there is a fit between the characteristics and constraints of the organizational environment and the type or organizational arrangements and members' characteristics, organizational effectiveness may be attained.

\section{The learning organization conception of organizational behaviour}

Senge (1980) developed the idea that organizations are dynamic entities that are based on knowledge. To be effective, an organization has to collectively generate knowledge in the best ways to achieve its goals. For him, there are five disciplines or processes that must take place for organizations to become performing organizations: 1) building shared vision; 2) creating mental models; 3) supporting team learning;4) developing personal mastery; and 5) achieving system thinking. The fifth discipline, system thinking, requires a conception of organizations as a complex, interrelated set of components that are in constant exchange. Goal attainment is achieved by pooling together knowledge from all members of the organization who share a common perspective and work in teams. Through trial and error, organizations "learn" how to respond to environmental constraints in ways that maximize their potential for goal attainment. Teamwork is crucial because it is required for producing new, functional knowledge conducive to achieving organizational effectiveness.

\section{Models of Leadership and Conceptions of Organizations}

In this section I try to map out the organizational conceptions that are at the root of some leadership models. The authoritarian, participative, contingency and distributed models of leadership will be discussed. 


\section{The authoritarian leadership model}

The traits of the authoritarian model of leadership have been described by Lewin, Lippit and White (1939) and Likert (1967). The characteristics they underscore are based on empirical findings and are similar. Most authors writing on leadership styles rely on the concept of authoritarian leadership, In this model, knowledge and expertise lie at the top. The leader imposes his/her views: since organization members are conceived as being short-sighted and as having little tolerance for ambiguity, clear orientations give them the security they need. Tasks are well defined and close supervision and control are exercised by the leader. Leaders are task oriented and formal structures are preferred to informal relations. Material rewards are employed to motivate employees (Taylor, 1911). Organizational goals and objectives are favoured and employees' relational needs get much less attention.

\section{The participative leadership model}

This model takes into account organization members' needs and expectations (McGregor, 1960; 1966). The basis for this model can be found in an empirical study by Likert (1967) on leadership styles. The study showed that organizations which adopted a participative leadership approach were more effective than those which adopted an authoritarian one.The study opened the way to a variety of management experiments such as management by objectives, organizational development, workers' empowerment and power sharing, among others. All these approaches to leadership depart from a strict top-down perspective. The members of the organization are at least consulted on organizational goals and on strategies to attain those goals. Organizational health is sought through matching organizational goals and members' needs (Argyris, 1964). This match, according to the model, ensures organizational effectiveness. Another version of this model is Blake and Mouton's leadership grid (1960). This grid consists of four quadrants resulting from the crossing of two management orientations: task orientation and interpersonal orientation. Effectiveness or ineffectiveness stems from a combination of these two orientations. The least effective of them is the "social club" combination in which the leader exerts a maximum of interpersonal orientation and a minimum of task orientation. Organizations that present this configuration of leadership are in an "anaemic" state. The optimum combination is that of maximum interpersonal orientation combined with a maximum of task orientation. However, both the least and most effective combinations are rarely found entirely in reality. 


\section{The contingency leadership model}

Fiedler $(1967 ; 1970 ; 1971 ; 1973)$ proposed a leadership model rooted in the contingency conception of organizations. What is important in this model is that the type of leadership depends on contingency factors. For him, the strategies that favour organizational effectiveness depend on leadership style (task or interpersonal relations) and three situational factors: leader-member relations, task structure, and power base. Thus, there is not a univocal leadership strategy to achieve organizational effectiveness. In fact, there are multiple ways of achieving it. As such, the type of leadership exerted depends on structural as well as interpersonal conditions. Another well-known model that could be linked to a contingency approach is that of Hersey and Blanchard (1977). In this leadership model, the main contingency factor is members' maturity. Leadership style would then vary according to level of maturity. When facing low competence and low commitment among members (unable, unwilling and insecure), the appropriate leadership should be a directing approach (high task focus, low relationship focus). When members show some competence and variable commitment (unable but willing or motivated), the leadership should be a selling/coaching approach (high task focus, high relationship focus). If members show high competence and variable commitment (able but unwilling or insecure), the leadership should be a participating/supporting approach (low task focus, high relationship focus). Finally, if members show high competence and high commitment (able and willing or motivated), the leadership should be a delegating/observing approach (low task focus, low relationship focus).

These two leadership approaches, however, do not take into account the external environment of organizations as a contingency conception would require. It adopts, however, the view that organizational effectiveness is not linked to a particular style of leadership. On the contrary, depending on the situation, the leader adopts responses which enhance effectiveness.

\section{The distributed leadership model}

Before discussing the relations between distributed leadership and the conception of a learning organization, I attempt to define more thoroughly the notion of distributed leadership. According to Hartley (2007), the concept of distributed leadership is somewhat elastic, and not a well-defined. He suggests that distributed leadership has become a kind of "social movement" (Hartley, 2007, p. 396). It is, in Gronn's terms, "the new kid on the block" (Gronn, 2006, p. 1). For Hartley, distributed leadership: 
... resonates with contemporary culture, with all of its loose affiliations and ephemeralities; and it is yet another sign of an institutional isomorphism whereby the public sector purports to legitimate its policies by appeal to the new organizational forms within the private sector (Hartley, 2007, p. 211).

Harris (2004) adopts Elmore's (2000) perspective on distributed leadership. Harris (2004), suggests that "distributed leadership [...] means multiple sources ${ }^{3}$ of guidance and direction, following the contours of expertise in an organization, made coherent through a common culture." Gronn (2002) advocates for a change in the unit of analysis of leadership, from a focused to a distributed or extended unit. He is against the "sacrosanct binaries or dualisms" such as "leader-followers" and "leadership-followership" (Gronn, 2002, p. 425). However, this perspective does not imply that there is no individual responsible for the overall performance of the organization. This is also the opinion of Spillane et al. (2007) who affirm that "a distributed perspective is not intended to negate or undermine the role of the school principal, but rather to extend our understanding of how leading and managing practices involves more than the actions of the school principal" (p. 104). What is meant by "distribution" is "maximizing the human capacity within the organization" (Harris, 2004, p. 14).

It should be noted that distributed leadership does not simply mean a delegation of power from one individual to others. Timperley (2005) states that "distributed leadership is not the same as dividing task responsibility among individuals who perform defined and separate organizational roles, but rather it comprises dynamic interactions between multiple leaders and followers" (p. 396)(see also Scribner et al., 2007). In fact, distributed leadership is "[the leadership] distributed over leaders, followers and the school situation or context" (Spillane et al., 2004, p. 11). Woods et al. (2004), in their review of the literature on distributed leadership, found three major characteristics of this type of leadership. Distributed leadership is an emergent property of a group or network of interacting individuals; it implies openness of the boundaries of leadership, widening the conventional leadership of teachers to other members of the school community; and it supposes a variety of expertise found across the many not the few. Two of these three characteristics are found in the work of Gronn (2002) who suggests that distributed leadership is an emergent condition of a group or network of individuals who pool their expertise.

A distinction by Spillane et al. (2007) helps to define distributed leadership. For him, there are two aspects of the distribution:"leader-plus” (Spillane et al., 2007, p. 108) and "practice" (Spillane et al., 2007, p. 109). The former implies multiple individuals 
not just at the top of the organization, while the latter refers to what is done in a particular time and place. This practice is the "product of interactions of school leaders, followers, and their situation" (p. 110). Spillane and Orlina (2005) further distinguish between collaborated, collective and coordinated distribution. Collaborated distribution is the leadership practice stretched over the work of two or more leaders who work together in place and time. Collective distribution is the leadership practice stretched over the work of two or more leaders who work separately but interdependently. Coordinated distribution encompasses leadership routines composed of two or more activities that have to be performed in a particular sequence. Finally, for Leithwood et al. (2007), there are two key conditions for successful leadership distribution: it should be distributed to those who can carry out the tasks expected of them and it has to be coordinated in some planned way.

The perspective of distributed leadership is congruent with the conception of "learning organization" in several aspects. First, the pursuit of organizational goals is not the matter of one individual, but of all members of the organization. It is through team learning that structures and systems are changed by pooling together members' expertise to achieve common goals. Members are "agents" who develop a systemic view of the organization and are active participants in shaping their reality (Senge, 1990). Second, distributed leadership assumes that organizational members develop a shared vision of the future they seek to create (Senge, 1990). Thus, there is encouragement for experimentation and innovation. Finally, distributed leadership supposes what Senge (1990) calls "personal mastery," that is commitment to "continually clarifying and deepening our personal vision, of focusing our energy, of developing patience, and of seeing reality objectively" (Senge, 1990, p. 7).

\section{Leadership Perspectives and Effectiveness}

Up to this point, leadership has been discussed in general, regardless of organizational fields and types of organizations. How do these leadership perspectives apply to the field of education? Which leadership perspective(s) is/are more effective within the realm of education? Stated differently, what are the relationships between leadership and school effectiveness and school improvement?

It should be stated that there is no systematic study on differential effectiveness of the various leadership perspectives discussed above. What is unchallenged today is that strong ${ }^{4}$ leadership has a traceable impact on educational achievement. 
But, what type of leadership? Several authors discuss the impact of a particular leadership style. However, a formal comparison, based on empirical data, on the differential impact of leadership approaches, is yet to come. Therefore, here I only discuss the effectiveness of distributed leadership as it is found in the recent literature, without assessing its impact relative to that of other leadership perspectives. But before presenting a summary of research findings on the effectiveness of distributed leadership, it is worth discussing in general the relationships between leadership and school effectiveness.

The effective schools research has its origins in the landmark study by Coleman on the effectiveness of school-related factors (Coleman et al., 1966). ${ }^{5}$ The study, confirmed by subsequent research (see Jencks et al., 1972), established that school variables had little impact on students' achievement and that the most important variables were those related to family background and socioeconomic status. These results raised, according to Jansen (1995), an enduring question in the research community: does school matter?

A pivotal study by Ronald Edmonds (1979), entitled Effective Schools for the Urban Poor, initiated the production of checklists of characteristics associated with effective schools. According to him, effective schools show the following characteristics: 1) strong administrative leadership; 2 ) a school climate conducive to learning; 3 ) high expectations for children's achievement; 4) clear instructional objectives for monitoring student performance; and 5) an emphasis on basic skills instruction. Other authors produced different checklists with varying numbers of sets of characteristics. Brookover and Lawrence (1979) introduced ten characteristics; the Phi Delta Kappa (1980) study identified eight properties of successful schools; and Austin (1981) put forward 29 characteristics of successful schools. However, Edmonds' list remains the list of reference for defining the contours of effective schools.

The optimism of the late 1970s and early 1980s based on studies of school effectiveness (Rutter et al., 1979; Teddlie and Stringfield, 1993; Teddlie and Reynolds, 2000) and the possibility of designing and implementing strategies leading to effectiveness gave way in the late eighties and early nineties to severe critiques of the effective schools hypothesis (Zirkel and Greenwood, 1987; Odden, 1990).

Fuelled by the shortcomings of the effective schools research, a new research trend developed, that of school improvement. This research trend is based on the work of Lewin $(1935 ; 1951)$ and on research on organizational development (Hopkins, 2001). This trend coincided with the systemic educational reform efforts of the decade of the nineties (Hopkins and Reynolds, 2001). 
Edmonds' checklist identified, as already noted, the principal's leadership as one of the five major factors in determining school effectiveness. This assertion has been confirmed by a string of both qualitative and quantitative research over the past twenty-five years. Van der Burg (1987), in a study of parents' perceptions of school effectiveness, identified strong leadership as one of its determinants. In that study, strong leadership ranked first out of 13 factors necessary for creating an effective school. Scieszka (1996) found also that, according to teachers' opinion, strong leadership is a key indicator of effective schools. Taking for granted the relevancy of strong leadership for school effectiveness, Blasé and Kirby (1992), as reported by Pritchett et al. (2000), noted fourteen traits of such leadership. Among these are resourcefulness, democratic-participatory style, problem-centredness, high expectations and knowledge of curricula. Hallinger and Heck (1996), in their review of empirical research between 1980 and 1995, found that the most predictive models used to study leadership effects indicate that effective leadership is mediated by the principal's influence on internal school processes. Doll (1996) indicated that principals in effective schools are close physically and psychologically to individual classrooms and schools. Leithwood and Jantzi (2000) empirically demonstrated that a leader's influence is important in the determination of school effectiveness and student achievement. Also, in their review of large-scale studies of schooling, Leithwood and Riehl (2003) found that leadership has a significant, albeit small, effect on student learning (Leithwood, Jantzi and McElheron-Hopkins, 2006; Leitwook \& Jantzi, 2006).

\section{Distributed leadership and organizational effectiveness}

Hartley (2007) states that there is very little evidence of a "direct causal relationship between distributed leadership and school achievement" (p. 202). With some notable exceptions, ${ }^{6}$ most of the studies on the effectiveness of distributed leadership have small samples and questionable methodologies.

Leithwood et al. (2007) noted that certain patterns of leadership distribution have a positive effect on organizational development and change. In a previous study, Leithwood and Jantzi (2000) found that distributing a larger proportion of leadership activity to teachers has a positive influence on teacher effectiveness and student engagement. Harris et al. (2007) identified a few studies that show an impact of distributed leadership. Among them, they discuss the studies by Elmore (2004), Fullan (2006) and Spillane (2006) that identify distributed leadership as one potential contributor to positive change and transformation in school systems. Also, Harris and Chapman's (2002), Moller et al.'s (2005) and Gurr et al.'s (2005) studies showed, according to this review, that improvements in the performance of schools were partly related to distributed leadership. 
Blasé and Blasé (1999), Portin (1998) and Hallinger (2000) found a positive relationship between organizational change and distributed forms of leadership practice. Louis and Marks (1996) found that professional learning communities were significant contributors to student achievement and that leadership within these communities is widely shared or distributed.

Harris (2004), in an earlier review of literature on distributed leadership, discusses a few studies that illustrate the effectiveness of distributed leadership. She cites, among others, Silns and Mulford's (2003) study showing that when leadership is distributed throughout the school community, students' outcomes are more likely to improve. She also notes that there is "clear evidence of the positive effect of distributed leadership on teachers' self-efficacy and levels of morale" (Harris, 2004, p. 15). But she concludes that "despite a wealth of school improvement literature advocating more collaborative, democratic and distributed forms of leadership, clear links with improved student outcomes have yet to be established" (p. 21). Leithwood et al. (2007) also conclude that "the existing empirical studies we have are still not extensive, fine grained or detailed enough to offer deep insights into the relationship between distributed leadership and organizational development. But the evidence is able to confirm that there is an important relationship between distributed leadership and organizational change which makes it worth further investigation and scrutiny" (p. 345).

\section{Concluding Remarks}

There are some barriers to overcome before a widespread adoption of distributed leadership takes place in schools (Harris, 2004). Schools are traditional hierarchies that are not prone to fostering distributed leadership. Also, the issues of how to distribute responsibility and who distributes it are major challenges within organizations.

Distributed leadership should not be seen as a latest trend in organizational studies that cries out to be implemented. It is not a ready-made solution to improving organizational effectiveness. One basic question to be answered is which schools are able to embrace and implement a distributed leadership approach. Is distributed leadership functional in disorganized organizational settings? Other questions that need to be addressed are: What degree of engagement and participation should be found in organization members to open the way to a distribution of leadership? Are 
the policies of the school that favour authority and responsibility to an established hierarchy conducive to a distribution of leadership? (See Fitzgerald \& Gunter, 2007)

Before endorsing a path leading to distributed leadership, it is important to progressively adopt participative and group decision-making behaviours and to test their effectiveness in organizational processes and goal attainment. It is not feasible to distribute leadership without knowing "theories-in-use" (Argyris \& Schön, 1974) of both the members of the school community and, perhaps more importantly, of the school principal. What are the profound reasons for the choices of organizational strategies and goal setting? What mechanisms should be put in place to reveal latent theories of action? Distributed leadership requires a questioning of the profound theories of action that are at the root of learning organizations. It requires the questioning of all five processes that must be in place for a learning organization to be effective (building a shared vision, creating mental models, supporting team learning, developing personal mastery and achieving system thinking), but in particular, achieving system thinking. According to Senge (1980), this is fundamental for improving organizational effectiveness.

\section{Notes}

1. See Spillane, Halverson \& Diamond (2004) for an alternative discussion of conceptions of organization and leadership models.

2. Drucker (1992) has also discussed the importance of knowledge within organizations. Argyris (1964) and Argyris \& Schön (1974) have also insisted on knowledge and learning within organizations.

3. Distributed leadership has even drawn the attention of the Sloan School of Management which is developing a distributed leadership model (Hartley, 2007).

4. Several factors have been associated with "strong" leadership. Blasé and Kirby (1992) identify factors such as initiative, confidence, tolerance for ambiguity, analytic abilities, resourcefulness, vision, listening, problem-centredness, openness, and high expectations.

5. The discussion on school effectiveness and school performance in this paper reproduces an unpublished analysis included in a grant proposal by Lynn ButlerKisber and Manuel Crespo.

6. For instance, the research programs conducted by K. Leithwood and by J.P. Spillane. 


\section{References}

Argyris, C. (1964). Integration the individual and the organization. NY: Wiley.

Argyris, C. \& Schön, D (1974). Theory in practice. Increasing professional effectiveness. San Francisco: Jossey-Bass.

Austin, G.R. (1981). Exemplary schools and their identification. Unpublished manuscript. Center for Educational Research and Development. University of Maryland.

Blake, R \& Mouton, J. (1960). The managerial grid: Key orientations for achieving production through people. Houston, TX: Gulf.

Blasé, J.R. \& Blasé, J. (1999). "Implementation of shared governance for instructional improvement: Principals' perspectives". Journal of Educational Administration, 37(5), 467-500.

Blasé, J.J. \& Kirby, P.C. (1992). Bringing out the best in teachers: What effective principals do. Thousands Oaks, CA: Corwin Press.

Bowess, D.G. \& Seashore, S.E. (1966). “Predicting organizational effectiveness with a fourfactor theory of leadership". Administrative Science Quarterly, 11, 238-263.

Brookover, W. \& Lawrence, L. (1979). Changes in school characteristics coincident with changes in student achievement. Occasional paper no. 17. Michigan, The Institute for Research on Teaching, University of Michigan.

Coleman, J., Campbell, E., \& Hobson, C. (1966). Equality of Educational Opportunities. Washington, DC: Department of Health, Education and Welfare.

Doll, R. (1996). Curriculum improvement: Decision making and process. Boston: Allyn and Bacon.

Drucker, Peter (1992). Managing for the future: the 1990s and beyond. New York; Toronto: Truman Talley Books/Dutton.

Edmonds, Ronald (1979). "Effective schools for the urban poor". Educational Leadership, $37,15-24$.

Elmore, R. (2000). Building a new structure for school leadership. Washington, DC: Albert Shanker Institute.
Elmore, R. (2004). School reform from inside out. Cambridge, MA: Harvard Education.

Emery, F. \& Trist, E. (1965). “The causal texture of organizational environments". Human Relations, 18, 21-32.

Fiedler, F.E. (1970). "Leadership experience and leader performance: another hypothesis shot to hell." Organizational Behavior and Human Performance, 5(2), 1-14.

Fiedler, F.E. (1973). "The contingency model: a reply to Ashour". Organizational and Human Performance, 9(3), 356-368.

Fiedler, F.E. (1971). Leadership. NY: General Learning Press.

Fiedler, F.E. (1967). A theory of leadership effectiveness. NY: McGraw-Hill.

Fitzgerald, T. \& Gunter, M. (2007). "Teacher leadership: A new myth for our time?" Paper presented at the Annual Meeting of AERA, Chicago, April 9-13.

Fullan, M. (2006). Turnaround leadership. San Francisco: Jossey Bass.

Gibb, C.A. (1954)." "Leadership". In G. Lindsey (ed.) Handbook of social psychology: vol. II. Special fields and applications, 877-920. Reading, MA: Addison Wesley.

Gronn, P. (2002). “Distributed leadership as a unity of analysis". The Leadership Quarterly, 13, 423-451.

Gronn, P. (2006)." The significance of distributed leadership". BC Educational leadership research. Retrieved October 30, 2006, from http://www.slc.educ.ubc.ca/eJournal//ssu e7/index7.html.

Gurr, D., Drysdale, L. \& Mulford, F. (2005). "Successful principal leadership: Australian case studies". Journal of Educational Administration, 42, 539-551.

Hallinger, P. (2000). "Educational change: Opening a window onto leadership as cultural process". School leadership and management, 20(2) , 189-205.

Hallinger, P. \& Heck, R. (1996). "Reassessing the principal's role in school effectiveness: A review of empirical research, 1980-1995". 
Educational Administration Quarterly, 32, 544.

Harris, A. (2004). "Distributed leadership and school improvement. Leading or Misleading?". Educational Management Administration \& Leadership, 32(1), 11-24.

Harris, A., Leithwood, K., Day, C. Sammoons, P., \& Hopkins, D. (2007). “Distributed leadership and organizational change: Reviewing the evidence". Journal of Educational Change, 8, 337-347.

Harris, A. \& Chapman, C. (2002). Effective leadership in schools facing challenging circumstances: Final report. Nottingham: NCSL.

Hartley, D. (2007). "The emergence of distributed leadership in education: Why now?". British Journal of Educational Studies, 55(2), 202-214.

Hersey, P. \& Blanchard, K.H. (1977). Management and organizational behaviour. Utilizing human resources. $3^{\text {rd }}$ edition. Englewoods Cliffs, NJ: Prentice Hall.

Hopkins, D. (2001). School improvement for real. London: Falmer Press.

Hopkins, D. \& Reynolds, D. (2001). "The Past, Present and Future of School Improvement: towards the Third Age". British Educational Research Journal, 27(4), 460-475.

Jencks, C., Smith, M., \& Ackland H. (1972). Inequality. New York: Basic Books.

Jansen, J.D. (1995). "Effective Schools?". Comparative Education, 31(2), 181-200.

Lawrence, P.P. \& Lorsch, J.N. (1986). Organization and Environment. Managing Differentiation and Integration. Boston, MA: Harvard Business School.

Leithwood, K. \& Jantzi, D. (2000). "The effects of transformational leadership on organisational conditions and student engagement". Journal of Educational Administration, 38(2), 112-129.

Leithwood, K. \& Jantzi, D. (2006) "Transformational school leadership for large-scale reform: Effects on students, teachers, and their classroom practices". School effectiveness and school improvement, 17(2), 201-207.
Leithwood, K. Jantzi, D., \& McElheron-Hopkins, C. (2006). "The improvement and testing of a school improvement model". School effectiveness and school improvement, 17(4), 441-464.

Leithwood, K., Mascall, B., Straup, J., Sacks, R., Memon, N., \& Yashkima, A. (2007). Distributing leadership to make school smarter. OISE: University of Toronto.

Leithwood, K. \& Riehl, C. (2003). What we know about successful school leadership. Philadelphia, PA:Temple University Press.

Lewin, K. (1935). A dynamic theory of personality. NY: McGraw-Hill.

Lewin, K. (1951). Field theory in social science; selected theoretical papers. D. Cartwright (Ed.). NY: Harper \& Row.

Lewin, K., Lippit. R., \& White, R.K. (1939). “Patterns of aggressive behaviour in experimentally created social climates". Journal of Social Psychology, 10, 271-301.

Likert, R. (1967). The human organization: Its management and value. New York: McGraw Hill.

Lorsh, J. \& Morse, J. (1974). Organizations and their members: A contingency approach. NY: Harper \& Row.

Louis, K. \& Marks, H. (1996). "Teachers' professional community in restructuring schools". American Educational Research Journal, 33(4), 757-789.

Mayo, E. (1960). The human problems of industrial civilization. NY:The Viking Press.

McGregor, D. (1960). The Human side of enterprise. Toronto: McGraw-Hill.

McGregor, D. (1966). Leaderhip and motivation. Essays. Cambridge, MA: MIT Press.

Mintzberg, H. (1979). The structuring of organizations: A synthesis of the research. Englewood Cliffs, NJ: Prentice Hall.

Moller, J., Eggen, A., Faglestad, O., Langfeldt, G., Presthus, A., \& Skrovset, S. (2005). "Successful school leadership: The Norwegian case". Journal of Educational Administration, 43(6), 584.

Odden A. (1990). "Class size and student achievement; research-based alternatives". 
Educational Evaluation and Policy Analysis, $12,213-227$.

Phi Delta Kappa (1980). Why do some urban schools succeed?. Bloomington, IN: Phi Delta Kappa.

Portin, B.S. (1998). “Compounding roles: A study of Washington' principals". International Journal of Educational Research, 29(4), 381-391.

Pritchett, J., Livingston, M., Schwartz, R.A., \& Slate, J.R. (2000). “What makes a good elementary school: A critical examination". The Journal of Educational Research, 93(6), 339-349.

Rutter, M., Manghan, B., Mortimore, P., \& Ouston, J. (1979). Fifteen Thousand Hours. London: Open Books.

Scieszka, G. (1996). Key indicators of effective rural elementary schools as perceived by parents and teachers. Unpublished doctoral dissertation. Boston College. Dissertation Abstracts International, 57, 09A: 3820.

Scribner, J.P., Sawyer, R.K., Watson, S.T., \& Meyers. V.L. (2007)." Teacher teams and distributed leadership: A study of group discourse and collaboration". Educational Administration Quarterly, 43(1), 67-100.

Senge. P. (1990). The fifth discipline: The art and practice of the learning organization. New York: Doubleday.

Silns, H. \& Mulford, B. (2003). "Leadership and school results". International Handbook of Educational Administration. Dordrecht: Kluwer.

Spillane, J.P. (2006). Distributed leadership. San Francisco: Jossey Bass.

Spillane, J.P., Halverson, R., \& Diamond, J.B. (2004). "Towards a theory of leadership practice: a distributed perspective."Journal of Curriculum Studies, 36(1), 3-34.
Spillane, J.P., Camburn, E.M., \& Pareja, A. S. (2007).

"Taking a distributed perspective to the school principal's workday". Leadership and Policy in Schools, 6, 103-125.

Spillane, J.P. \& Orlina, E.C. (2005). “Exploring the entailments of taking a distributed perspective". Leadership and Policy in Schools, 4, 157-176.

Taylor, F.W. (1911). The principles of scientific management. New York: Harper.

Teddlie, C. \& Reynolds, D. (2000). The International Handbook of School Effectiveness Research. London: Farmer Press.

Teddlie, C. \& Stringfield, D. (1993). Schools make a difference: lesson learned from a ten-year study of school effects. New York: Teachers' College Press.

Timperley, H.S. (2005). "Distributed leadership: developing theory from practice". J. Curriculum Studies, 37(4), 395-420.

Van der Burg, K. (1987). Effective school characteristics: A comparison of administrator and parent perspectives. Unpublished doctoral dissertation, University of WisconsinMadison. Dissertation Abstracts International, 48, 081: 1987.

Weber, M. (1968). Economy and society: an outline of interpretative sociology. New York: Badminster Press.

Woods, P.A., Bennette, N., Harvey, J.A., \& Wise, C. (2004). "Variabilities and dualities in distributed leadership. Findings from a systematic literature review". Educational Management Administration and Leadership, 32(4), 439-457.

Woodward, J. (1965). Industrial organizations: Theory and practice. London: Oxford University Press.

Zirkel, P.A. \& Greenwood, S.C. (1987). "Effective schools and effective principals: effective research?". Teachers' College Record, 89, 255-267. 


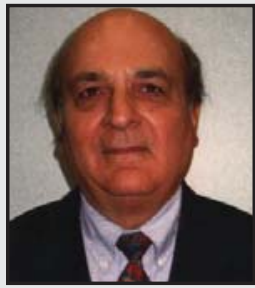

Manuel Crespo is Professor of Educational Administration at Université de Montréal. His areas of interests are comparative educational administration, comparative higher education, program evaluation, sociology of education, and sociology of organizations. In his career he has held a wide range of senior administrative positions in the Faculty. As well, he has published extensively and has served as director or principal researcher for a number of national and international projects. His work has been extensively funded by organizations such as UNESCO and the Social Sciences and Humanities Research Council of Canada. From 2002 to 2006, he co-directed The Trinidad and Tobago Educational Leadership Project for 43 inservice Ministry officials, principals and vice-principals. Recently, he was invited to serve as expert for the assessment of teacher education in Rwanda and Mauritania. He also presently coordinates the Commission for Evaluation of Quality in Higher Education of the Ministry of Higher Education, Science and Technology of the Dominican Republic. 